\title{
Commentary: Looking before leaping
}

\author{
Dawn S. Hui, MD, ${ }^{a}$ and Richard Lee, MD, MBA ${ }^{\mathrm{b}}$
}

From the ${ }^{\mathrm{a} D e p a r t m e n t}$ of Cardiothoracic Surgery, University of Texas Health Science Center at San Antonio, San Antonio, Tex; and ${ }^{\mathrm{b}}$ Division of Cardiothoracic Surgery, Department of Surgery, Medical College of Georgia, Augusta University, Augusta, Ga.

Disclosures: Authors have nothing to disclose with regard to commercial support.

Received for publication Sept 23, 2019; revisions received Sept 23, 2019; accepted for publication Sept 24, 2019; available ahead of print Sept 30, 2019.

Address for reprints: Richard Lee, MD, MBA, Department of Surgery, Medical College of Georgia, 1120 15th St, BA-4300, Augusta, GA 30912 (E-mail: richardleemdmba@gmail.com or RICKLEE@augusta.edu).

J Thorac Cardiovasc Surg 2021;161:634-5

$0022-5223 / \$ 36.00$

Copyright (c 2019 by The American Association for Thoracic Surgery

https://doi.org/10.1016/j.jtcvs.2019.09.088

In this edition of The Journal, Dreifaldt and colleagues ${ }^{1}$ report on the no-touch technique of saphenous vein (SV) harvesting. The study, designed as a non-inferiority randomized trial, showed no angiographic difference between radial artery (RA) and SV conduits at 8-year angiographic followup after coronary artery bypass grafting. These findings support the authors' Central Message, which is that a no-touch SV graft may be an excellent complementary conduit to arterial grafts. However, to conclude as they do in their Perspective that this "increases the number of situations in which SV is preferable to radial artery grafts" is a leap. A look at the design and methods of the study reveals why we challenge this message.

The first issue is the generalizability of the findings. Over a recruitment period of 5.5 years, only 109 patients were enrolled, equating to less than 20 per year. This may be explained by the fairly strict exclusion criteria such as age $>65$ years, left ventricular ejection fraction $<40 \%$, and even renal dysfunction that was only mild (serum creatinine $>120 \mu \mathrm{mol}$ ). Although the rationale for the age cutoff was to obtain longer-term follow-up, other studies have shown that elderly age is not prohibitive to late follow-up. ${ }^{2,3}$ Further, these restrictions resulted in a study cohort that is markedly dissimilar to the patients most likely referred for surgery over percutaneous coronary intervention, since the benefit of coronary artery bypass grafting is greatest for patients with diabetes and those with low systolic function. The cohort, being rarely diabetic $(19 \%)$ or smokers $(14 \%)$, is also one in whom the potential challenges of a second arterial graft may be hardly applicable. Finally, women composed only $12 \%$ of the cohort. Some contemporary studies show that women continue to receive less complete revascularization, ${ }^{4,5}$ whereas the Cleveland Clinic found the opposite-women generally receive less frequent use of multiple arterial and RA grafts. ${ }^{6,7}$ Any study that may potentially promote such practices should also ensure adequate representation of this subgroup.

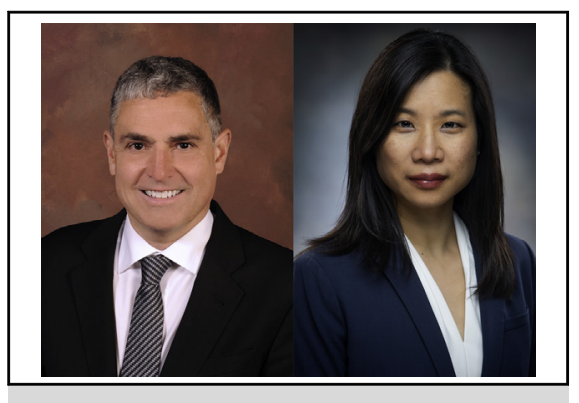

Richard Lee, MD, MBA, and Dawn S. Hui, MD

Central Message

Advances in vein harvest techniques may promote improved patency, but whether this proves to be an acceptable alternative or preferable to arterial grafts remains in question.

See Article page 624.

In addition to patient factors, the practices employed in this study do not reflect contemporary clinical judgment regarding RA grafts. This includes anastomosis to vessels with as low as $50 \%$ stenosis and lack of routine use of calcium channel blockers for RA, which has demonstrated association with better angiographic and clinical outcomes in the RADIAL (Radial Artery Database International ALliance) analysis of 6 trials. ${ }^{8}$ Unlike the RADIAL and Arterial Revascularization Trial (ART) ${ }^{9}$ studies, clinical endpoints such as all-cause mortality, cardiovascular events, and need for repeat revascularization are not reported here. Another outcome to consider is whether the necessary open leg incisions will be acceptable to patients, surgeons, and the cardiologists who refer such patients. Unfortunately, the incidence of leg wound infections was not reported. Contemporary populations are likely to be afflicted with diabetes and obesity, which raise the risk of wound infection. Further, all patients in this study received both RA and SV. To replace RA with additional SV would impose additional incision and wound burdens. In a small study, patients who had undergone open RA and SV harvest reported greater scar discomfort from the SV site, both in the short and long term. ${ }^{10}$ The rise of endoscopic vein harvesting was driven by the morbidity of open vein harvest; thus, the preferability of open SV is questionable. In short, the finding of this study is limited: no-touch SVG may be non-inferior to RA in a restricted population, and only in terms of angiographic patency. To draw further conclusions, or state as the authors do that SV would be preferable to RA, is to overstep bounds. 


\section{References}

1. Dreifaldt M, Mannion JD, Geijer H, Liden M, Bodin L, Souza D. The no-touch saphenous vein is an excellent alternative conduit to the radial artery 8 years after coronary artery bypass grafting: a randomized trial. J Thorac Cardiovasc Surg. 2021;161:624-30.

2. Habib RH, Schwann TA, Enogren M. Late effects of radial artery versus saphenous vein grafting in patients aged 70 years or older. Ann Thorac Surg. 2012;94: 1478-84.

3. Modine T, Al-Ruzzeh S, Mazrani W, Azeem F, Bustami M, Ilsley C, et al. Use of radial artery graft reduces the morbidity of coronary artery bypass graft surgery in patients aged 65 years and older. Ann Thorac Surg. 2002;74:1144-7.

4. Nicolini F, Vezzani A, Fortuna D, Conitini GA, Pacini D, Gabbiere D, et al. Gender differences in outcomes following isolated coronary artery bypass grafting: long-term results. J Cardiothorac Surg. 2016;11:144.

5. Ter Woorst JF, van Straten AHM, Houterman S, Soliman-Hamad MA. Sex difference in coronary artery bypass grafting: preoperative profile and early outcome. $J$ Cardiothorac Vasc Anesth. 2019;33:2679-84.

6. Attia T, Koch CG, Houghtaling PL, Blackstone EH, Sabik EM, Sabik JF III. Does a similar procedure result in similar survival for women and men undergoing isolated coronary artery bypass grafting? J Thorac Cardiovasc Surg. 2017;153: $571-9$.

7. Lawton JS, Barner HB, Bailey MS, Guthrie TJ, Moazami N, Pasque MK, et al. Radial artery grafts in women: utilization and results. Ann Thorac Surg. 2005; 80:559-63.

8. Gaudino M, Benedetto U, Fremes SE, Hare DL, Hayward P, Moat N, et al. Effect of calcium-channel blocker therapy on radial artery grafts after coronary bypass surgery. J Am Coll Cardiol. 2019;73:2299-306.

9. Taggart DP, Altman DG, Gray AM, Lees B, Gerry S, Benedetto U, et al. Randomized trial of bilateral versus single internal-thoracic-artery grafts. $N$ Engl J Med. 2015;375:2540-54.

10. Zhu YY, Hayward PAR, Hadinata IE, Matalanis G, Buxton BF, Stewart AG, et al. Long-term impact of radial artery harvest on forearm function and symptoms: a comparison with leg vein. J Thorac Cardiovasc Surg. 2013; 145:412-9. 